\title{
Stability of reef fish assemblages: responses to coral recovery after catastrophic predation by Acanthaster planci
}

\author{
Mitsuhiko Sano* \\ Department of Global Agricultural Sciences, Graduate School of Agricultural and Life Sciences, The University of Tokyo,
} Yayoi, Bunkyo-ku, Tokyo 113-8657, Japan

\begin{abstract}
A long-term monitoring study was conducted at Iriomote Island (Ryukyu Islands, Japan) to explore the responses of a disturbed adult fish assemblage to the recovery of coral on a large reef degraded by an outbreak of the coral-feeding starfish Acanthaster planci. In 1987, 5 yr after the outbreak, I censused a reef in which all of the arborescent corals had been broken apart and the reef formation changed into a flat plain of unstructured rubble. Species richness and numerical density of fishes on the dead reef had decreased severely. Natural recovery of the dead reef was initiated mainly by larval recruitment of branching Acropora corals in 1989. Since that time, fish species richness and density on the recovering reef have increased steadily with the increasing percentage cover of live corals. In 1995 to 1997, when the reef had almost $100 \%$ live coral cover, most fish assemblage properties (e.g., species numbers and abundances of the collective assemblage and component ecological groups) on the reef did not differ significantly from those on a nearby reef consisting mostly of arborescent Acropora, which had not suffered A. planci predation. The similarity index indicated about $90 \%$ resemblance in species composition of the fish assemblages on the recovered and undisturbed reefs. These results demonstrate that the structure of the disturbed fish assemblage had returned to its preperturbation state on the near-completion of coral recovery.
\end{abstract}

KEY WORDS: Coral reef degradation - Fish assemblage $\cdot$ Recovery $\cdot$ Stability $\cdot$ Acanthaster planci

\section{INTRODUCTION}

Natural communities are subjected to a multitude of biotic and abiotic perturbations. Because such perturbations often produce substantial changes in the composition and structure of communities (Begon et al. 1986), establishing the ability of communities to return to their pre-perturbation states, i.e., stability (Holling 1973, Pimm 1991), has been a major theme of community ecology.

Since the early 1960s, mass mortality of hermatypic corals following outbreaks of the coral-feeding starfish Acanthaster planci has been documented at various localities throughout the Indo-Pacific (e.g., Birkeland \& Lucas 1990). The biological and physical environments

\footnotetext{
•E-mail: amsano@mail.ecc.u-tokyo.ac.jp
}

of the infested reefs changed strikingly after predation by the starfish (e.g., Endean 1973, Hutchings 1986). Such widespread and intense reef degradation had significant effects on the structure of reef fish assemblages in some locations (Sano et al. 1984a, 1987, Bouchon-Navaro et al. 1985, Williams 1986, but see Hart et al. 1996). Sano et al. (1987) found, for example, that A. planci-induced habitat destruction (extensive coral depletion and simplified topography) was correlated with severe decreases in fish species number and density on a large reef in the Ryukyu Islands, Japan.

Despite the apparently catastrophic damage to coral reefs by Acanthaster planci infestation, recovery of coral assemblages has recently been reported from several local sites (Birkeland \& Lucas 1990, Done et al. 1991. Connell 1997). If successional changes in the structure of markedly impacted fish assemblages during the progress of coral recovery can be monitored 
and the assemblage structure on completely recovered reefs compared with that occurring before perturbation or on undisturbed reefs, it is feasible to comment on the stability of fish assemblages on large, contiguous reefs. This type of study has been infrequently conducted, although some manipulative experiments have involved the observation of recolonization patterns on small denuded patch reefs (Smith 1973, Sale \& Dybdahl 1978, Brock et al. 1979).

This paper describes the results of a long-term study in which I examined the patterns of responses of a disturbed adult fish assemblage to continuing coral recovery on a large reef degraded by an outbreak of Acanthaster planci. I ask whether the fish assemblage returned to its pre-perturbation state or was characterized by a different structure, by comparing the assemblage associated with the recovering reef and one over an undisturbed reef over an $8 \mathrm{yr}$ period. Moreover, using the long-term monitoring data, I ascertain whether or not the dynamics and structure of the fish assemblage on the undisturbed, contiguous reef were constant or varied from year to year.

\section{METHODS}

The study was conducted on the fringing reefs of Amitori and Sakiyama bays $\left(24^{\circ} 20^{\prime} \mathrm{N}, 123^{\circ} 42^{\prime} \mathrm{E}\right)$, situated on the western side of Iriomote Island, one of the Ryukyu Islands of Japan, from 1987 to 1997 (Fig. 1). At Amitori Bay, hermatypic corals, especially Acropora and Pocillopora spp., were very heavily infested with Acanthaster planci between 1981 and 1982, and were completely killed by the end of 1982 . The extensive mortality of these corals precipitated major changes in the physical and biological environment of the reef (see Sano et al. 1987). By 1986, all of the dead arborescent corals at the study site (ca 2 ha) on the reef had collapsed drastically due to biological and physical erosion. As a result, the reef structure was converted into a flat plain of coral rubble coated with coralline algae and a deposit of silt. This unstructured rubble reef is referred to hereafter as 'dead reef'. It had persisted with no sign of recovery until around 1988, but subsequently underwent natural recovery due mainly to larval recruitment of branching Acropora. This reef, subsequent to 1989 , is referred to as 'recovering reef'.

The Sakiyama Bay reef, on the other hand, was selected as an undisturbed, reference area. The study site (ca $2 \mathrm{ha}$ ) within the reef had not experienced the Acanthaster planci outbreak, and consisted mostly of extensive thickets of living arborescent Acropora, having high structural complexity. Live coral cover was more than $95 \%$ during the study period. This site is referred to as 'living reef'. Both study sites at Amitori and Sakiyama bays, separated by a distance of about $2 \mathrm{~km}$, were similar in some environmental features, such as water depth (ca $1 \mathrm{~m}$ at low tide), exposure to wave action, and reef morphology. I presumed, therefore, that fish assemblages were similar between these 2 sites before the A. planci outbreak occurred.

Visual censuses were made on the dead reef in October 1987 and on the recovering and living reefs between September and November (mostly October), every year from 1990 to 1997 . At each census, 5 nonoverlapping belt transects $20 \mathrm{~m}$ long and $1 \mathrm{~m}$ wide were established haphazardly on each reef using a scaled rope. The rope was laid $5 \mathrm{~min}$ prior to censusing fishes to reduce biases due to disturbance. After this recovery period, each transect was approached slowly using a mask and snorkel. Roving fishes (e.g., acanthurids, chaetodontids, labrids, and scarids), which moved over larger areas and across the transect, were first enumerated for $10 \mathrm{~min}$. Resident fishes (e.g. blenniids, gobiids, and most pomacentrids), which were resident within the transect area, were then counted by swimming along the transect and carefully inspecting the entire area until all visible residents were recorded. Individual fish were identified to species level, and then the number of adults of each spe-

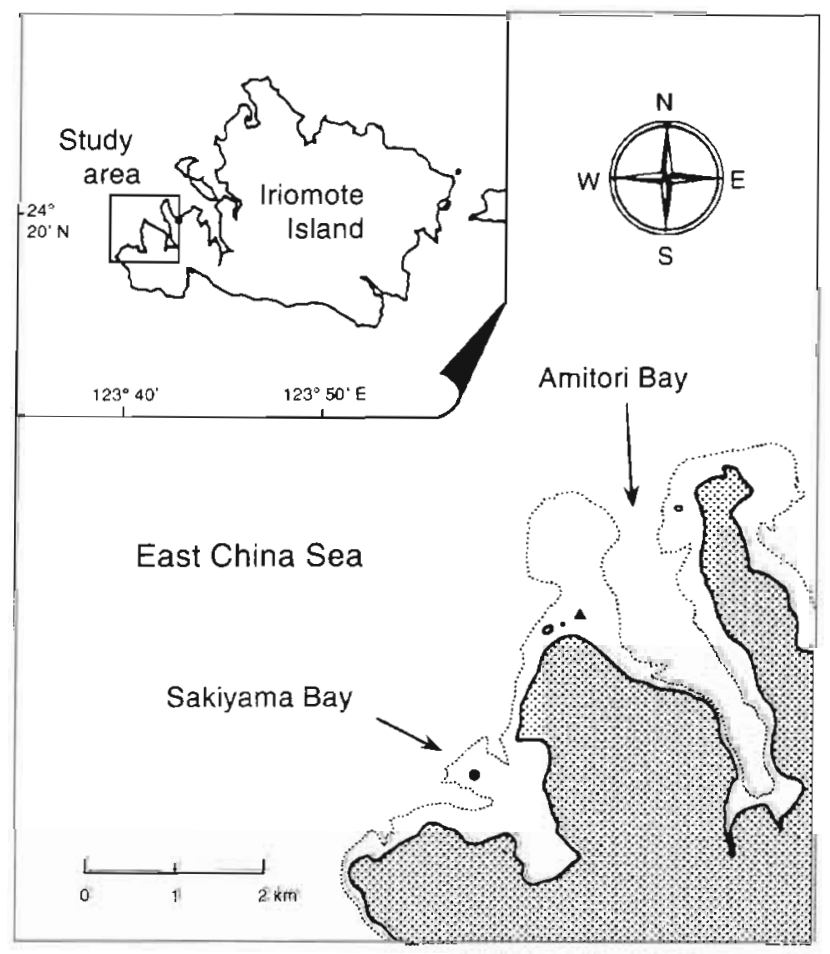

Fig. 1. Map of the study area at Iriomote Island, Ryukyu Islands, Japan. Dotted line indicates reef margin. (•) Living reef; $(\mathbf{\Lambda})$ dead and subsequently recovering reef 
cies was recorded on a plastic slate. Adults were identified by their size and coloration. All censuses were made at high tide between 10:00 and 15:00 $\mathrm{h}$ and each transect was censused once. Species richness and density of fishes on each reef are expressed as the mean numbers of species and individuals per transect $\left(20 \mathrm{~m}^{2}\right.$, 5 transects reef ${ }^{-1}$ ), respectively.

On the completion of each fish census, to determine the cover of live hard corals on each reef, benthic surveys were conducted within each transect used for the fish census. All live corals included within the entire area of each transect $\left(20 \mathrm{~m}^{2}\right)$ were identified to species, and their surface area was approximately measured using a scaled tape. Since the dead reef was predominately recolonized by 2 branching corals, Acropora brueggemanni and Acropora nobilis, which were the most dominant species on the living reef during the study period, the mean percentage cover of all live corals per transect $(n=5)$ was used as the degree of restitution of the coral assemblage on the recovering reef.

To ascertain changes in the trophic structure of the fish assemblage with degree of coral recovery, fishes censused were assigned to 1 of 6 trophic categories, as defined by published dietary data (e.g., Hiatt \& Strasburg 1960, Hobson 1974, Sano et al. 1984b, Sano 1989, Allen 1991) and my underwater observations of the feeding behavior of each species. The trophic categories involved herbivores, omnivores (including planktivores, which feed on drifting algae and zooplankton), corallivores, which prey exclusively on scleractinian corals, benthic-animal feeders, which consume benthic invertebrates other than corals, zooplanktivores, and piscivores.

Data analyses employed the MINITAB statistical package. A 2-sample $t$-test was used to evaluate any difference in fish assemblage structure between the living reef and recovering reef each year and to determine when the impacted fish assemblage was restored to its original state. Wiens \& Parker (1995) pointed out that this type of analysis over a long period following an environmental disturbance is highly available for assessing its biological impacts and subsequent recovery, when there are no data before the disturbance. A 1-way analysis of variance (ANOVA) was also used to examine temporal variations in assemblage structure on the living reef over the 8 yr period. Prior to the analyses, data were transformed to $\log (x+1)$ and variances tested for homogeneity using Bartlett's test. When variances were heterogeneous, the Welch and non-parametric KruskalWallis tests were performed instead of the $t$-test and ANOVA, respectively.

For assessing the overall similarity of the fish assemblages on the reefs (dead or recovering reef vs living reef) each year, and between-year similarities of the assemblages on the living reef, I computed the proportional similarity index (PS) (Linton et al. 1981):

$$
P S=1-0.5 \sum_{i=1}^{n}\left|P_{x i}-P_{y i}\right|
$$

where $P_{x i}$ and $P_{y i}$ are the proportions of individuals of species $i$ in assemblages on reefs $x$ and $y$ or on the living reef in years $x$ and $y$, and $n$ is the total number of species. This index ranges from 0 (no similarity) to 1 (complete similarity). In this analysis, census data pooled across 5 transects on each reef were used, and data from the 1990 living reef were substituted for those of the 1987 living reef, which was not censused.

\section{RESULTS}

\section{Coral recovery}

Temporal changes in percentage cover of live corals on the recovering reef over the study period are shown in Table 1. Live coral cover continued to increase from 1989, attaining $100 \%$ in 1995. At that time, the reef was dominated by extensive thickets of Acropora brueggemanni and A. nobilis; the proportional coverage by each of these species did not differ significantly between the recovering $(A$. brueggemanni, 69.5 [mean] $\pm 8.0 \%$ [SD] per transect, $\mathrm{n}=5$; A. nobilis, $30.5 \pm 8.0 \%)$ and living $(49.0 \pm 19.5 \%$ and $43.5 \pm 24.5 \%$, respectively) reefs (Mann-Whitney test: $U=19, \mathrm{p}=0.208$ for $A$. brueggemanni; $U=15.5$. $\mathrm{p}=0.600$ for $A$. nobilis).

Table 1. Annual changes in mean percentage cover of live corals per transect $\left(20 \mathrm{~m}^{2}, \mathrm{n}=5\right)$ on the dead (1987) and subsequently recovering (1990 to 1997) reef during the study period

\begin{tabular}{|ccc|}
\hline Year & \multicolumn{2}{c|}{ Live coral cover $(\%)$} \\
& Mean $\pm \mathrm{SD}$ & Approximate mean \\
& & \\
\hline 1987 & $0 \pm 0$ & 0 \\
1990 & $42.0 \pm 2.74$ & 60 \\
1991 & $58.0 \pm 2.74$ & 70 \\
1992 & $71.6 \pm 2.30$ & 80 \\
1993 & $81.0 \pm 2.24$ & 90 \\
1994 & $93.5 \pm 1.37$ & 100 \\
1995 & $100 \pm 0$ & 100 \\
1996 & $100 \pm 0$ & 100 \\
1997 & $98.0 \pm 2.74$ & \\
& \\
& \\
&
\end{tabular}




\section{Fish recovery}

The fish fauna associated with the transects on the living reef over the 8 yr period was made up of 94 species. The total number of species present on the reef in any given year varied from 50 to 61 (Fig. 2A). Of these, the 4 most common fishes, Pomacentrus moluccensis, Atrosalarias fuscus holomelas, Cheiloprion labiatus, and Chaetodon trifasciatus, accounted for 55 to $58 \%$ of all sighted fish per year. The mean numbers of species and individuals per transect on the living
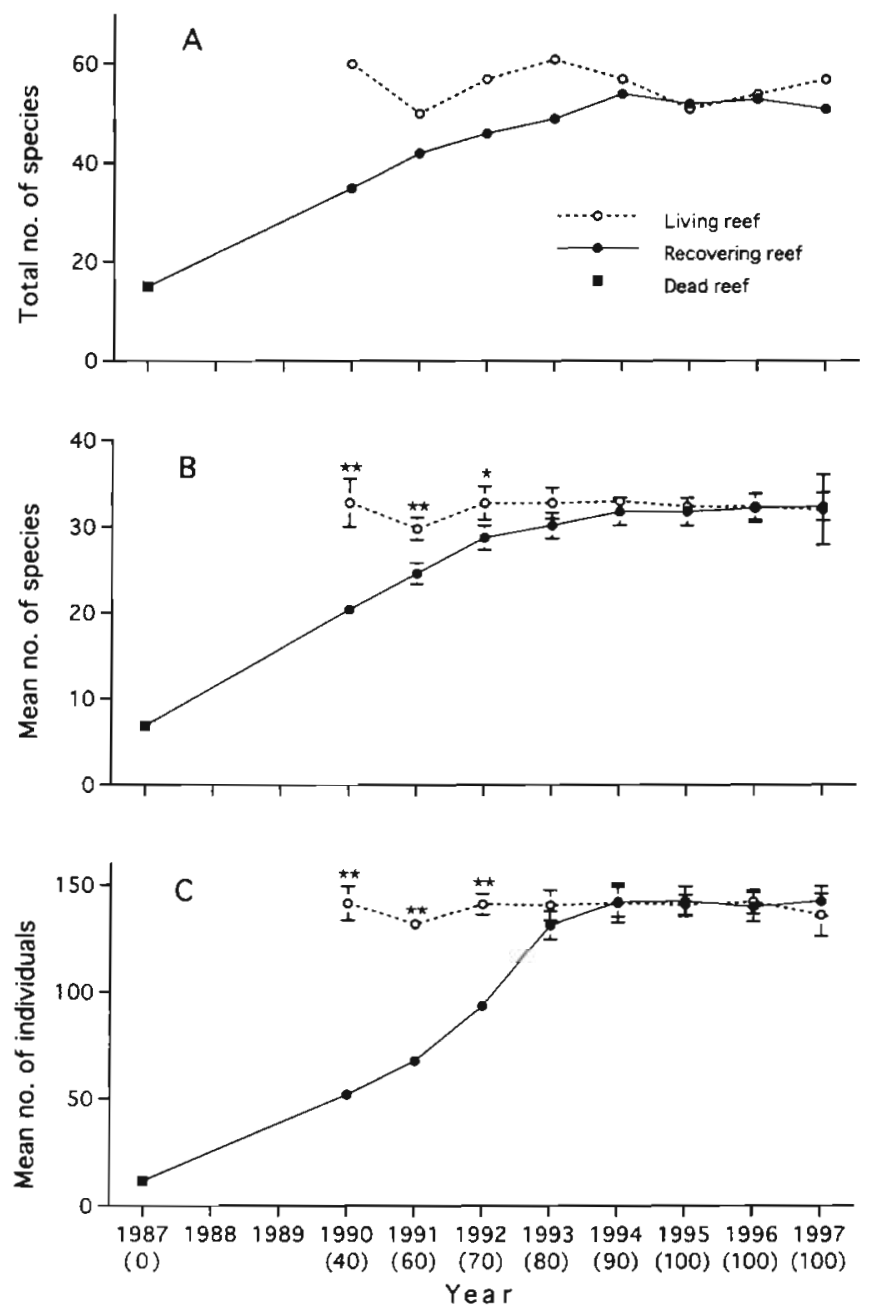

Fig. 2. (A) Total number of species over 5 transects and $(B, C)$ mean numbers $( \pm \mathrm{SD})$ of $(B)$ species and $(C)$ individuals per transect $\left(20 \mathrm{~m}^{2}, \mathrm{n}=5\right)$ on each reef from 1987 to 1997. Numbers in parentheses represent approximate mean percentage cover of live corals per transect on the dead (1987) and subsequently recovering (1990 to 1997) reef. "Significant differences in the mean species number and density of fishes between the living reef and recovering reef each year (2-sample $t$-test or the Welch test): ${ }^{\star} p<0.05 ;{ }^{\star \star} p<0.01$. In this analysis, the comparison between the living reef and dead reef in 1987 was not performed, because the former reef was not censused reef remained fairly constant during the $8 \mathrm{yr}$ of observation (Fig. 2B,C), with no significant differences among years (Kruskal-Wallis test, $H=8.67, p=0.278$ for species richness; 1-way ANOVA, $F=1.36, p=0.257$ for fish density).

Compared with the living reef, total species richness and mean numbers of species and individuals per transect were markedly lower on the dead reef. These 3 variables steadily increased with increasing live coral cover on the recovering reef, and then stayed relatively unchanged after complete coral restoration (Fig. 2A to C). The latter 2 variables showed no significant differences between the living and recovering reefs, once the recovering reef had attained $80 \%$ or more live coral cover (1993 to 1997) ( $t$ - or Welch test, $p>0.15$ in all analyses, see Fig. 2B,C).

The trophic structure of the fish assemblage on the living reef varied little with time (Figs. 3 \& 4). The mean numbers of species and individuals per transect in each trophic category on the living reef did not differ significantly among years (1-way ANOVA, see Table 2). Zooplanktivores and piscivores were excluded from this and the following analyses, because fish in these categories were rare.

Comparisons of species richness and fish abundance in each trophic category among the 3 kinds of reefs indicated that the lowest numbers of species and individuals were obtained from the dead reef for all categories. For herbivores, omnivores, and corallivores, numbers on the recovering reef increased with the increasing coral recovery, and became similar to those on the living reef when live coral cover on the recovering reef reached about $80 \%$ or more ( $t$ - or Welch test, all $p>0.10$, Figs. $3 \& 4$ ). Benthic-animal feeders, on the other hand, showed no particular response to the amount of live coral cover. Species and individual numbers in this group showed no significant differences between the living and recovering reefs in most years after 1990, at which time the recovering reef had $40 \%$ live coral cover $(t$ - or Welch test, all $\mathrm{p}>0.10$ ). However, only in 1992 and 1993 were significantly greater numbers counted on the recovering reef ( $t$-test, all p $<0.02$, Figs. $3 \& 4$ ).

To examine the responses of the adult fish assemblage on the recovering reef to increases in food (especially corals) and living space with shelter (i.e., branching coral substratum) associated with coral recovery, 2 ecological groups (roving corallivores and resident planktivores) were constructed on the basis of both trophic category and residency. I anticipated that resident planktivores - which feed primarily on water column zooplankton and drift algae, the availability of which is probably not influenced by coral restoration - would respond to the amount of living space. On the other hand, roving corallivores, which 

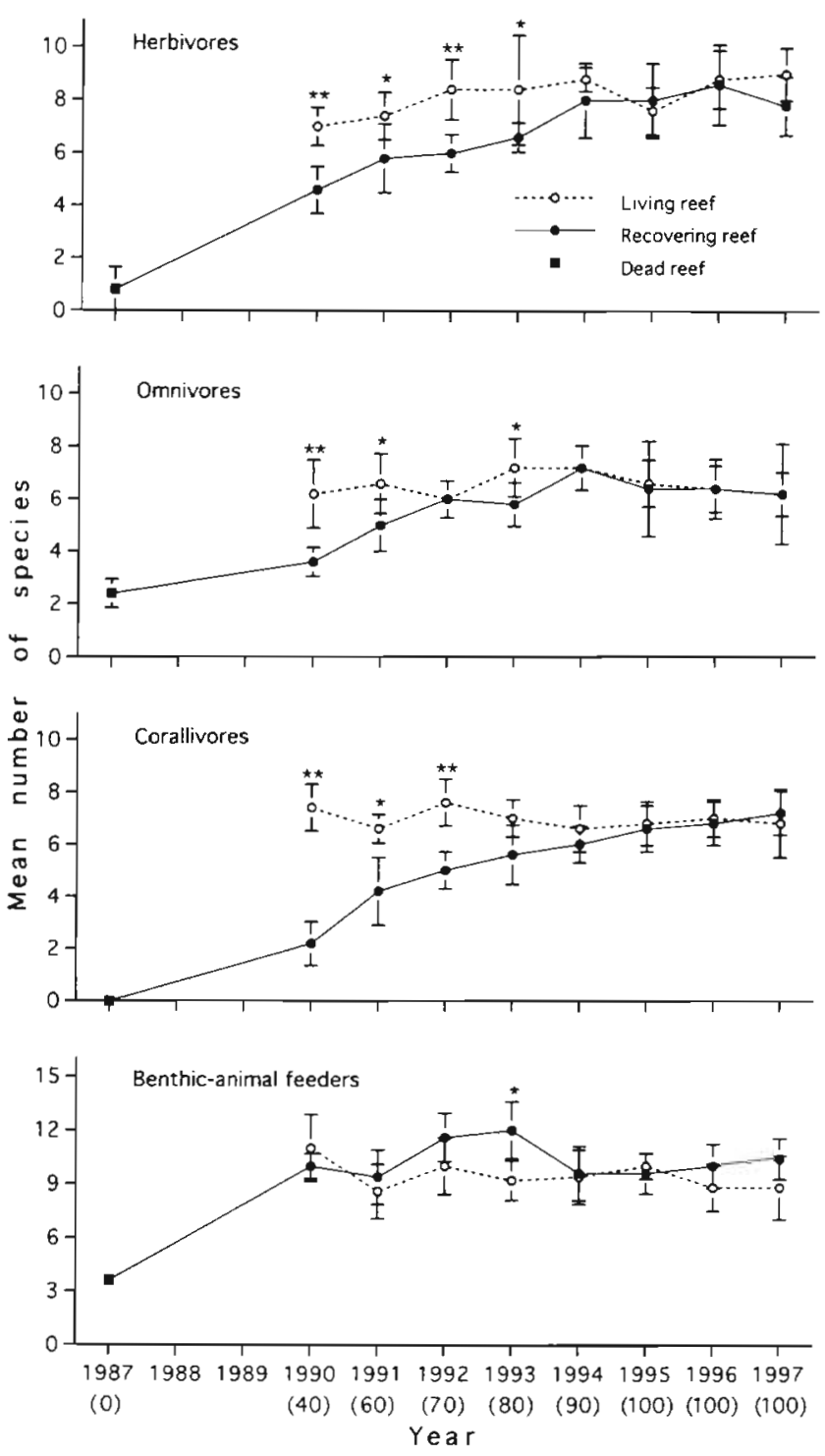

Fig. 3. Mean number $( \pm \mathrm{SD})$ of species per transect $\left(20 \mathrm{~m}^{2}\right)$ for each trophic group on each reef from 1987 to 1997. See Fig. 2 legend for further details

are not closely dependent on coral substratum for shelter, would respond to coral abundance as food.

There were no significant differences in the mean numbers of species and individuals of resident planktivores and roving corallivores on the living reef among years ( 1 -way ANOVA, $F=0.55, \mathrm{p}=0.788$ and $F=1.45$, $\mathrm{p}=0.219$ for the numbers of species and individuals of resident planktivores, respectively; $F=0.93, p=0.499$ and $F=1.68, p=0.149$ for roving corallivores; Figs. 5 $\& 6)$. Numbers for both groups were lowest on the dead reef. Following the onset of coral recovery, the numbers on the recovering reef rose steadily with coral abundance, matching those on the living reef when coral cover had attained $80 \%$ or more $60 \%$ or more for
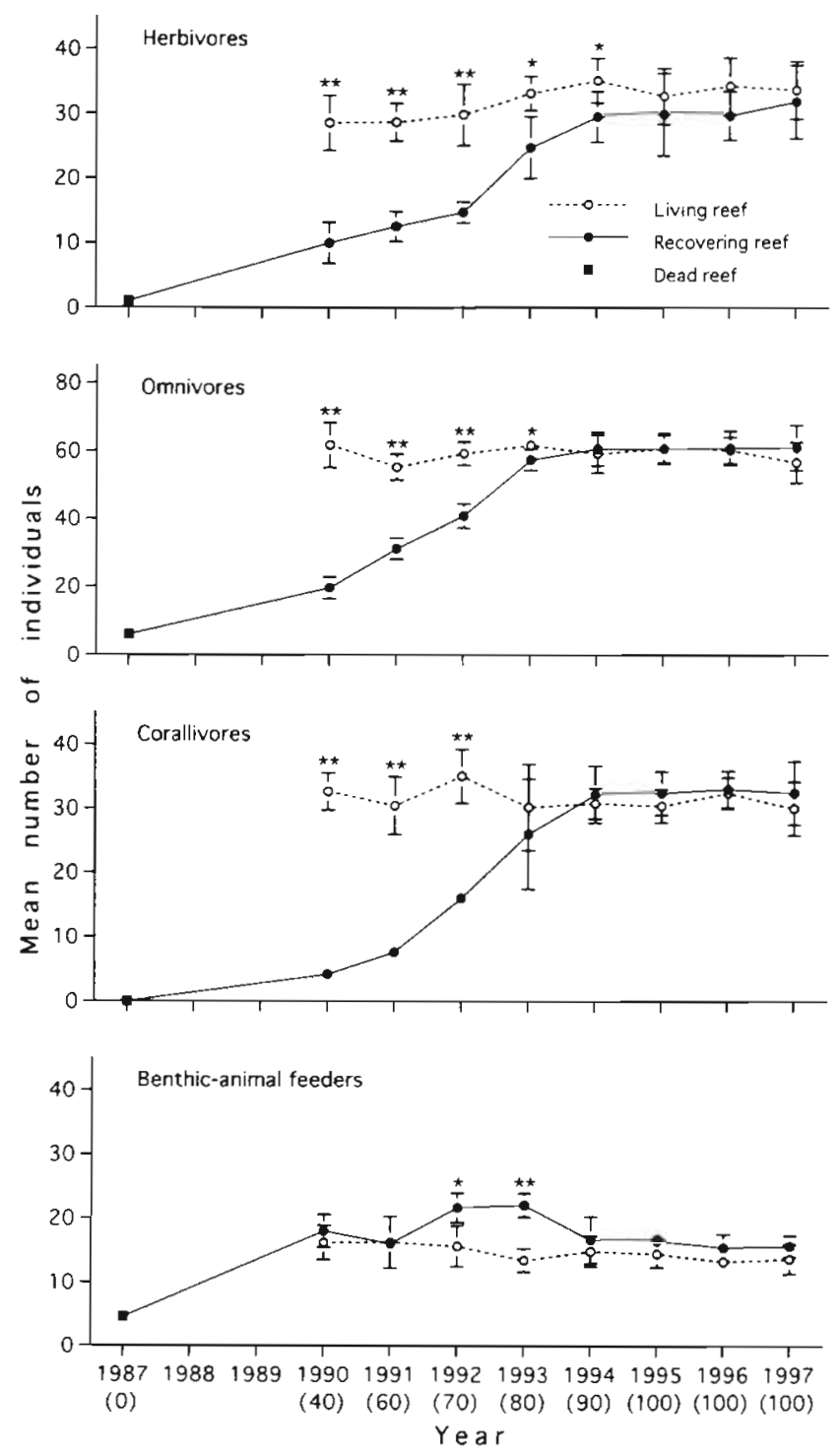

Fig. 4. Mean number $( \pm \mathrm{SD})$ of individuals per transect $\left(20 \mathrm{~m}^{2}\right)$ for each trophic group on each reef from 1987 to 1997 . See Fig. 2 legend for further details

Table 2. Results of 1-way ANOVAs testing temporal variations in the mean numbers of species and individuals per transect $\left(20 \mathrm{~m}^{2}, \mathrm{n}=5\right)$ in each trophic category on the living reef over the 8 yr period (1990 to 1997)

\begin{tabular}{|c|c|c|c|c|}
\hline \multirow[t]{2}{*}{$\begin{array}{l}\text { Trophic } \\
\text { category }\end{array}$} & \multicolumn{2}{|c|}{$\begin{array}{l}\text { No. of } \\
\text { species }\end{array}$} & \multicolumn{2}{|c|}{$\begin{array}{c}\text { No. of } \\
\text { individuals }\end{array}$} \\
\hline & $F$ & $p$ & $F$ & $\mathrm{p}$ \\
\hline Herbivores & 2.01 & 0.085 & 2.22 & 0.059 \\
\hline Omnivores & 0.81 & 0.587 & 1.26 & 0.303 \\
\hline Corallivores & 0.83 & 0.569 & 0.95 & 0.480 \\
\hline $\begin{array}{l}\text { Benthic-animal } \\
\text { feeders }\end{array}$ & 1.44 & 0.222 & 1.05 & 0.419 \\
\hline
\end{tabular}



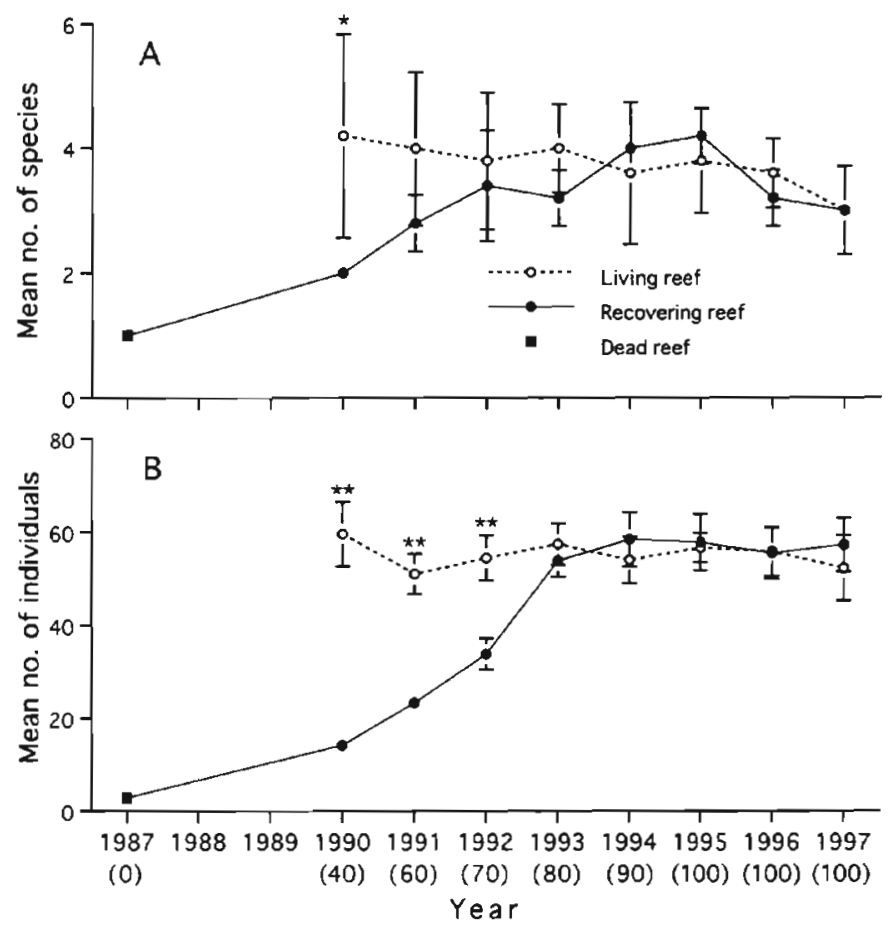

Fig. 5. Mean numbers $( \pm S D)$ of $(A)$ species and $(B)$ individuals per transect $\left(20 \mathrm{~m}^{2}\right)$ for resident planktivores on each reef from 1987 to 1997 . See Fig. 2 legend for further details
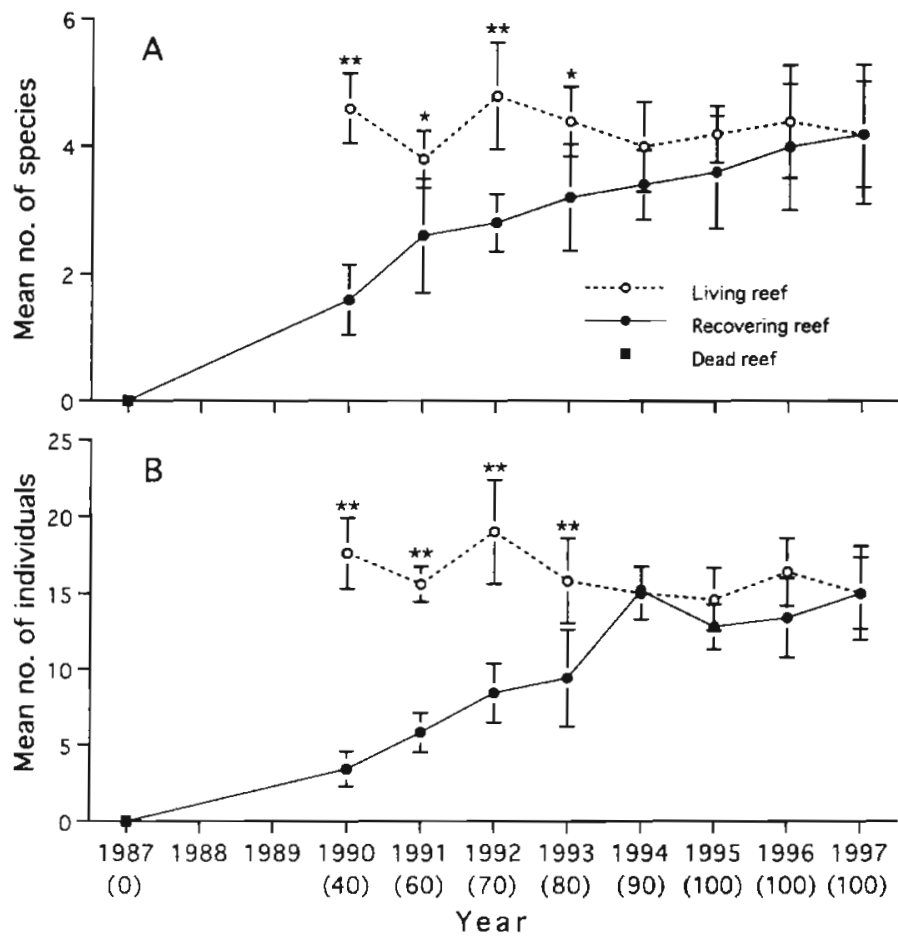

Fig. 6. Mean numbers ( $\pm \mathrm{SD}$ ) of (A) species and (B) individuals per transect $\left(20 \mathrm{~m}^{2}\right)$ for roving corallivores on each reef from 1987 to 1997 . See Fig. 2 legend for further details the number of resident planktivorous species) ( $t$ - or Welch test, all $p>0.06$, Figs, $5 \& 6$ ).

The mean numbers of individuals per transect of the 4 most common species on the living reef, the resident planktivore Pomacentrus moluccensis, resident herbivore Atrosalarias fuscus holomelas, resident corallivore Cheiloprion labiatus, and roving corallivore Chaetodon trifasciatus, remained fairly constant during the $8 \mathrm{yr}$ (1-way ANOVA, $F=0.88, \mathrm{p}=0.533$ for $P$. moluccensis; $F=1.31, p=0.276$ for $A$. fuscus holomelas; $F=0.52, \mathrm{p}=0.812$ for $C$. labiatus; $F=1.11$, $\mathrm{p}=0.382$ for $C$. trifasciatus; Fig. 7). These species had completely disappeared on the dead reef, but showed
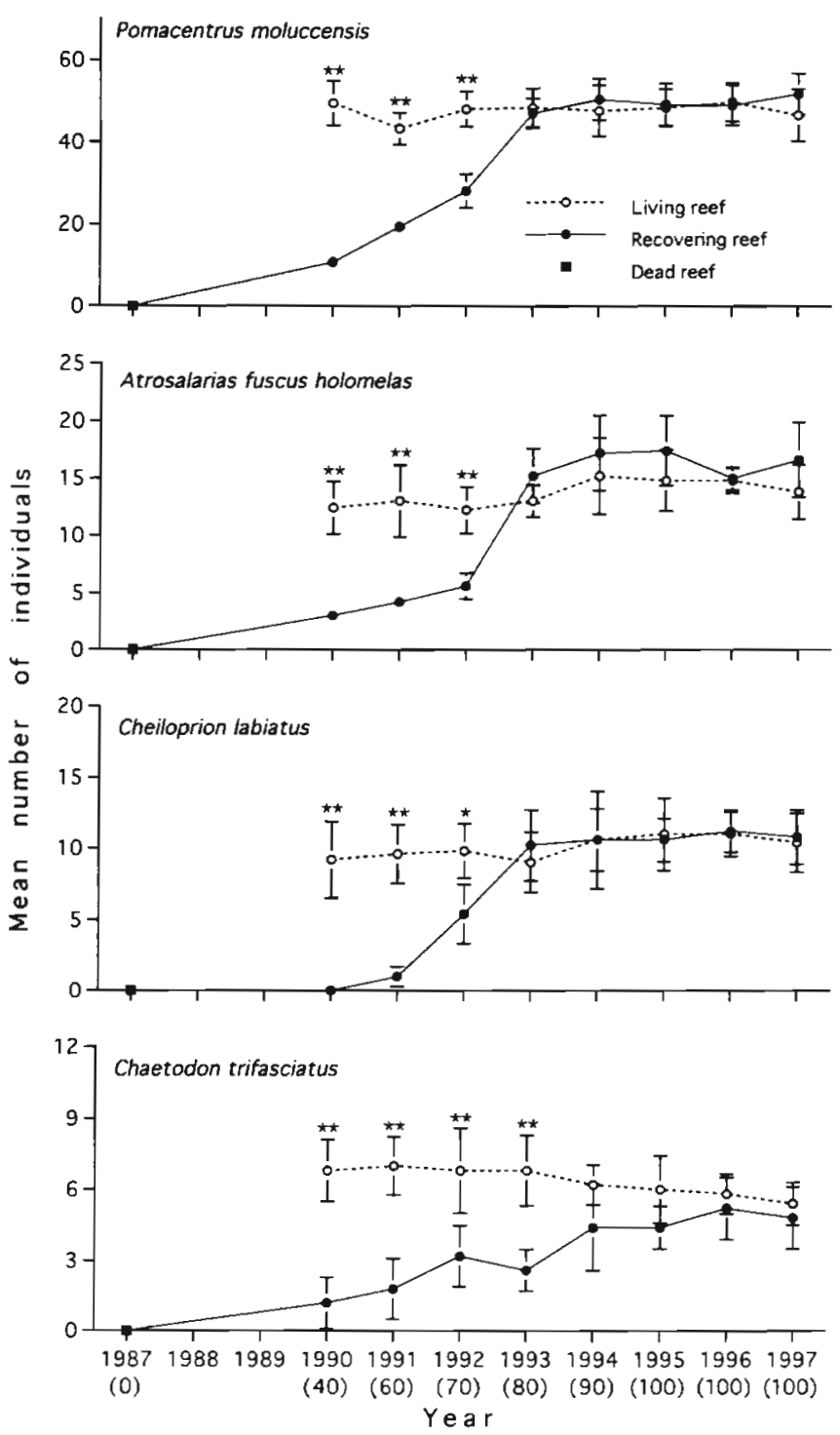

Fig. 7. Temporal dynamics of abundance for each of the 4 most dominant species on the living and recovering reefs. Data indicate mean (per transect, $20 \mathrm{~m}^{2}$ ) $\pm \mathrm{SD}$. See Fig. 2 legend for further details 


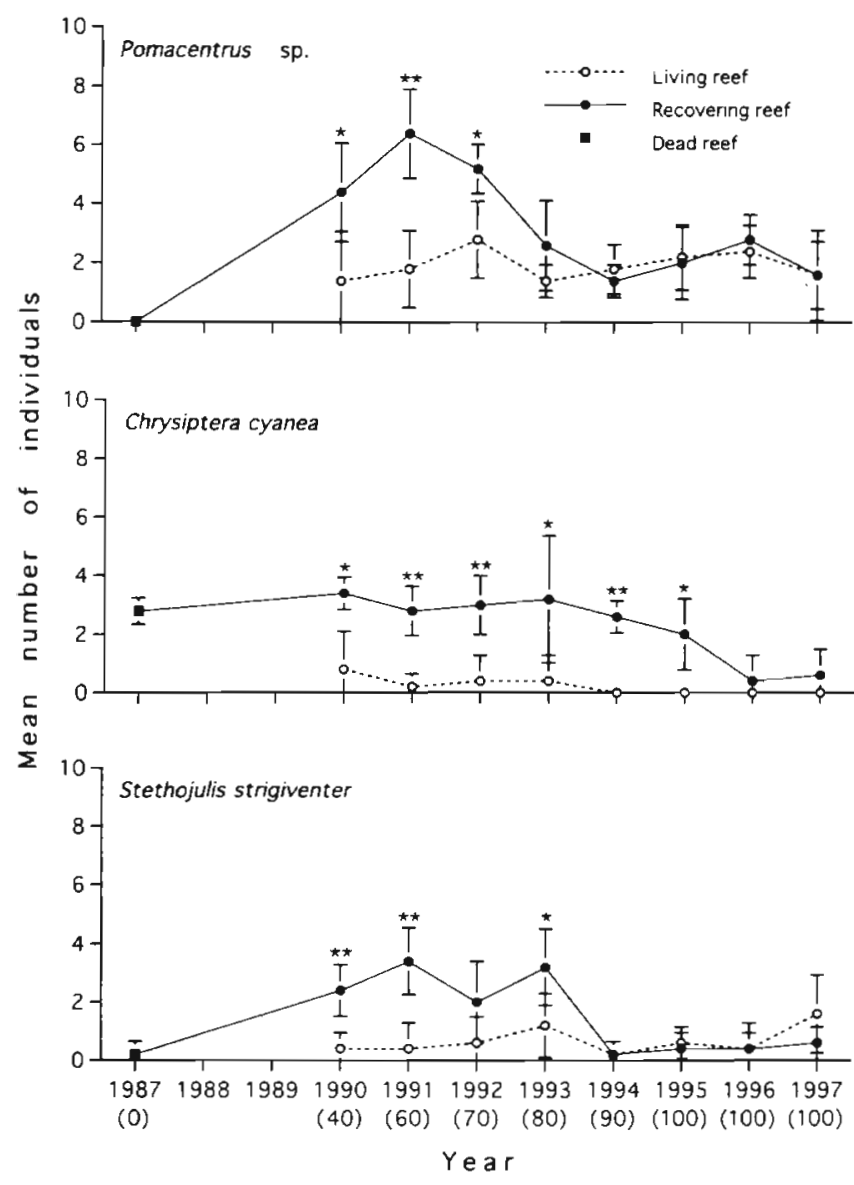

Fig. 8. Mean number $( \pm \mathrm{SD})$ of individuals per transect $\left(20 \mathrm{~m}^{2}\right)$ for each of 3 species (Pomacentrus sp., Chrysiptera cyanea, and Stethojulis strigiventer) on each reef from 1987 to 1997. See Fig. 2 legend for further details

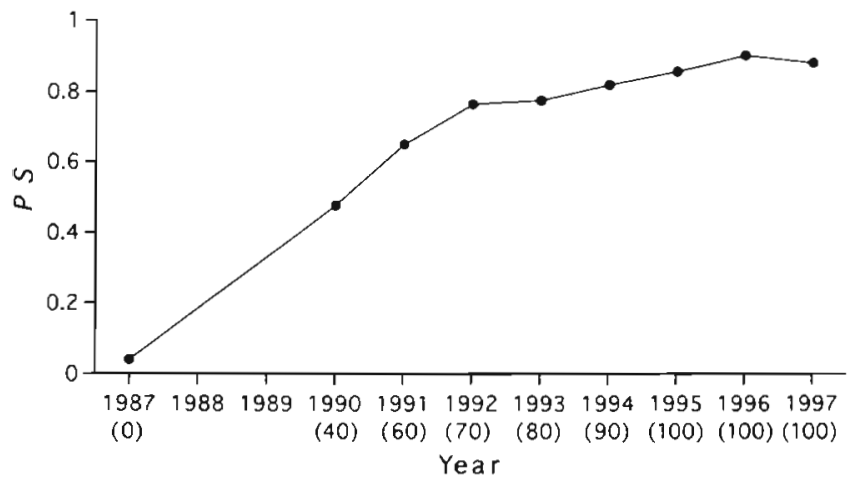

Fig. 9. Temporal changes in the proportional similarity index $(P S)$ of fish assemblages between the living reef and dead or recovering reefs each year. Numbers in parentheses indicate approximate mean percentage cover of live corals per transect $\left(20 \mathrm{~m}^{2}\right)$ on the dead and recovering reefs. In this analysis, the 1987 dead reef was compared to the 1990 living reef trends of increasing abundance on the recovering reef similar to that of the total number of individuals shown in Fig. $2 \mathrm{C}$ (Fig. 7 ).

The 2 resident omnivores, Pomacentrus sp. and Chrysiptera cyanea, and the roving benthic-animal feeder Stethojulis strigiventer, on the other hand, occurred in significantly greater abundance on the moderately recovered reef than on the living reef ( $t$ - or Welch test, all $p<0.05$, Fig. 8). Abundances of these 3 species, however, revealed no significant differences between the living and recovering reefs when coral cover of the latter had reached near $100 \%$ ( $t$ - or Welch test, all $p>0.06$, Fig. 8).

Using the proportional similarity index, I calculated the between-year similarity of the fish assemblage on the living reef. Of 28 possible pairs of years, all yielded values greater than 0.85 , with a mean of $0.892 \pm 0.016$ (SD).

The similarity of assemblages between the living and dead or recovering reefs each year is shown in Fig. 9. The dead reef was most dissimilar (0.040) from the living reef. Similarity continued to increase with increasing live coral cover on the recovering reef, the $100 \%$ recovered reef in 1995 to 1997 resulting in high similarity values $(>0.85$ ), with a maximum of 0.903 in 1996.

\section{DISCUSSION}

The results of this study demonstrate that the structure of the adult fish assemblage, substantially altered by Acanthaster planci-induced habitat destruction, returned to its pre-perturbation state on the near-completion of coral recovery. Species richness and density of fishes on the recovering reef matched those on the living reef when live coral cover had attained $80 \%$ or more. In addition, the similarity index represented about $90 \%$ resemblance in species composition of the assemblages on the living and 100\% recovered reefs. Connell \& Sousa (1983) claimed that the minimum time period needed to judge the stability of a natural community is at least 1 complete turnover of all component individuals. Although I cannot say that my study would satisfy such a rigorous criterion, it is clear that the recovery of the disturbed assemblage demonstrated a great deal of stability, rather than shifting to a different configuration.

Recovery patterns of the disturbed assemblage structure were highly predictable from the extent of coral recovery. Most fish assemblage properties examined (i.e., species numbers and densities of collective assemblage and ecological groups, except for benthicanimal feeders, and densities of dominant species) showed steady increases with the increasing percent- 
age cover of live arborescent corals (Figs. 2 to 7 ). These results suggest that live coral cover plays an important role in determining the structure of the fish assemblage at the spatial scale observed in the present study. Live corals probably provide food not only for corallivores (e.g., Hourigan et al. 1988, Mcllwain \& Jones 1997) but also for other trophic groups, because numerous organisms which serve as food for many reef fishes are associated with live coral heads and their dead basal parts (Sorokin 1993). Furthermore, areas with greater live coral cover tend to be more structurally or topographically complex (Jones \& Syms 1998), providing living space with shelter for reef fishes, especially residents (Sano et al. 1987, Clarke 1996, Beukers \& Jones 1997, Lewis 1997a). In this study, planktivorous residents showed significant increases in the numbers of species and individuals during the progress of coral recovery (Fig. 5). The amount of live coral cover, therefore, may limit the availability of benthic resources, such as food and living space, for a number of reef fishes.

Studies concerning relationships between fish assemblage attributes and live coral cover, however, have produced conflicting results. Some studies have found positive correlations (e.g., Carpenter et al. 1981, Bell \& Galzin 1984, Bouchon-Navaro \& Bouchon 1989, Chabanet et al. 1997, Munday et al. 1997), while others have found little or none (e.g., Luckhurst \& Luckhurst 1978, Roberts \& Ormond 1987, Fowler 1990, Cox 1994 , Friedlander \& Parrish 1998). These disparate results may be due partly to different sampling methods used. The spatial scales of sampling, location of study sites within a reef, and range of changes in habitat variable measured potentially affect the consequences of habitat association studies (Roberts \& Ormond 1987, Munday et al. 1997, Jones \& Syms 1998). Hence, to reach a general understanding of the influences of live coral cover on reef fish assemblages, experimental work with the appropriate scale of analysis and a wider range of coral cover will have to be conducted in each reef habitat. Recently, using a manipulative field experiment, Lewis (1997a) demonstrated that several attributes of fish assemblages on natural patch reefs (108 to $267 \mathrm{~m}^{2}$ in planar area) were sensitive to reductions in live coral cover.

My results showed the structure of the adult fish assemblage on the large, undisturbed living reef to be fairly constant from year to year. None of the assemblage properties analyzed differed significantly among the $8 \mathrm{yr}$, and values of between-year similarity ranged from 0.864 to 0.933 (mean 0.892 ). These findings contradict those of Sale et al. (1994), who found that overall fish assemblages (adults + juveniles) on patch reefs ( 3 to $32 \mathrm{~m}^{2}$ in surface area) varied substantially in structure throughout time over a $10 \mathrm{yr}$ period. Such a contrast indicates that the picture of temporal dynamics of reef fish assemblages may be different between overall and adult-only assemblages or between isolated patch reefs and large, contiguous reefs. Many workers have disclosed that recruitment of reef fishes varies markedly in time and space (reviews by Doherty \& Williams 1988, Doherty 1991, Booth \& Brosnan 1995). Such recruitment variations possibly have a greater impact on the dynamics and structure of an overall (rather than just adult) assemblage, although evidence exists that adult density directly reflects interannual variation in recruitment in some reef fishes (Doherty \& Williams 1988, Doherty \& Fowler 1994). Moreover, it seems likely that within a contiguous reef, fish occurring in crowded areas set up by variable patchy recruitment can move into sparser areas due to the lack of barriers to movement, resulting in a constant density in each area over time (Sale et al. 1994, Sale 1996). Post-recruitment movements among habitat patches within reefs have been documented for many reef fishes (e.g., Frederick 1997, Lewis 1997b).

The general conclusion that can be drawn from my long-term monitoring data set is that the disturbed adult fish assemblage on the Acanthaster planci-damaged reef at Iriomote Island showed a steady and predictable return to its original state with the progression of coral recovery. I do not believe, however, that this recovery pattern is the general nature for reef fish assemblages. Available evidence to date reveals that processes structuring assemblages vary from place to place, because of a multiplicity of factors, including variable recruitment, competitive and predatory interactions, and disturbance (e.g., reviews by Ebeling \& Hixon 1991, Jones 1991, Caley et al. 1996). Further studies are required to determine whether or not perturbed fish assemblages on contiguous reefs in other locations exhibit a similar recovery pattern.

Acknowledgements. I thank the many people who have made this long-term study possible. In particular, I am indebted to Hiroyuki Yokochi, Hiroyoshi Kohno, Nagahiro Nakazato, Hisatoshi Baba, Ken Sakihara, and the Okinawa Regional Research Center, Tokai University, for assisting in the field work. Comments on the manuscript from Peter Sale, Charles Birkeland, Graham Hardy, and anonymous reviewers were very helpful. This study was supported in part by Grants-in-Aid for Scientific Research from the Ministry of Education, Science, Sports and Culture of Japan (Nos. 02760109, 05660200, and 09660193), and is a contribution from the Okinawa Regional Research Center.

\section{LITERATURE CITED}

Allen GA (1991) Damselfishes of the world. Mergus, Melle Begon M, Harper JL, Townsend CR (1986) Ecology: individucils, populations and communities. Blackwell Scientific Publications, Oxford 
Bell JD, Galzin R (1984) Influence of Live coral cover on coralreef fish communities. Mar Ecol Prog Ser 15:265-274

Beukers JS, Jones GP (1997) Habitat complexity modifies the impact of piscivores on a coral reef fish population. Oecologia 114:50-59

Birkeland C, Lucas JS (1990) Acanthaster planci: major management problem of coral reefs. CRC Press, Boca Raton

Booth DJ, Brosnan DM (1995) The role of recruitment dynamics in rocky shore and coral reef fish communities. Adv Ecol Res 26:309-385

Bouchon-Navaro Y, Bouchon C (1989) Correlations between chaetodontid fishes and coral communities at the Gulf of Aqaba (Red Sea). Environ Biol Fishes 25:47-60

Bouchon-Navaro Y, Bouchon C, Harmelin-Vivien ML (1985) Impact of coral degradation on a chaetodontid fish assemblage (Moorea, French Polynesia). Proc 5th Int Coral Reef Congr Tahiti 5:427-432

Brock RE, Lewis C, Wass RC (1979) Stability and structure of a fish community on a coral patch reef in Hawaii. Mar Biol $54: 281-292$

Caley MJ, Carr MH, Hixon MA, Hughes TP, Jones GP, Menge BA (1996) Recruitment and the local dynamics of open marine populations. Annu Rev Ecol Syst 27:477-500

Carpenter KE, Miclat RI, Albaladejo VD, Corpuz VT (1981) The influence of substrate structure on the local abundance and diversity of Philippine reef fishes. Proc 4th Int Coral Reef Symp Manila 2:497-502

Chabanet $\mathrm{P}$, Ralambondrainy H, Amanieu M, Faure G, Galzin $R$ (1997) Relationships between coral reef substrata and fish. Coral Reefs 16:93-102

Clarke RD (1996) Population shifts in two competing fish species on a degrading coral reef. Mar Ecol Prog Ser 137 . $51-58$

Connell JH (1997) Disturbance and recovery of coral assemblages. Coral Reefs 16(Suppl):101-113

Connell JH, Sousa WP (1983) On the evidence needed to judge ecological stability or persistence. Am Nat 121: $789-824$

Cox EF (1994) Resource use by corallivorous butterflyfishes (family Chaetodontidae) in Hawaii. Bull Mar Sci 54:535-545

Doherty PJ (1991) Spatial and temporal patterns in recruitment. In: Sale PF (ed) The ecology of fishes on coral reefs. Academic Press, San Diego, p 261-293

Doherty PJ, Fowler AJ (1994) An empirical test of recruitment limitation in a coral reef fish. Science 263: 935-939

Doherty PJ, Williams DMcB (1988) The replenishment of coral reef fish populations. Oceanogr Mar Biol Annu Rev 26: $487-551$

Done TJ, Dayton PK, Dayton AE, Steger R (1991) Regional and local variability in recovery of shallow coral communities: Moorea, French Polynesia and central Great Barrier Reef. Coral Reefs 9:183-192

Ebeling AW, Hixon MA (1991) Tropical and temperate reef fishes: comparison of community structures. In: Sale PF (ed) The ecology of fishes on coral reefs. Academic Press, San Diego, p 509-563

Endean R (1973) Population explosions of Acanthaster planci and associated destruction of hermatypic corals in the Indo-West Pacific region. In: Jones OA, Endean R (eds) Biology and geology of coral reefs, Vol II. Biology 1. Academic Press, New York, p 389-438

Fowler AJ (1990) Spatial and temporal patterns of distribution and abundance of chaetodontid fishes at One Tree Reef, southern GBR. Mar Ecol Prog Ser 64:39-53

Frederick JL (1997) Post-settlement movement of coral reef fishes and bias in survival estimates. Mar Ecol Prog Ser $150: 65-74$
Friedlander AM, Parrish JD (1998) Habitat characteristics affecting fish assemblages on a Hawaiian coral reef. J Exp Mar Biol Ecol 224:1-30

Hart AM, Klumpp DW, Russ GR (1996) Response of herbivorous fishes to crown-of-thorns starfish Acanthaster planci outbreaks. II. Density and biomass of selected species of herbivorous fish and fish-habitat correlations. Mar Ecol Prog Ser 132:21-30

Hiatt RW, Strasburg DW (1960) Ecological relationships of the fish fauna on coral reefs of the Marshall Islands. Ecol Monogr 30:65-127

Hobson ES (1974) Feeding relationships of teleostean fishes on coral reefs in Kona, Hawaii. Fish Bull 72:915-1031

Holling CS (1973) Resilience and stability of ecological systems. Annu Rev Ecol Syst 4:1-23

Hourigan TF, Tricas TC, Reese ES (1988) Coral reef fishes as indicators of environmental stress in coral reefs, In: Soule DF, Kleppel GS (eds) Marine organisms as indicators. Springer-Verlag, New York, p 107-135

Hutchings PA (1986) Biological destruction of coral reefs: a review. Coral Reefs 4:239-252

Jones GP (1991) Postrecruitment processes in the ecology of coral reef fish populations: a multifactorial perspective. In: Sale PF (ed) The ecology of fishes on coral reefs. Academic Press, San Diego, p 294-328

Jones GP, Syms C (1998) Disturbance, habitat structure and the ecology of fishes on coral reefs. Aust $J$ Ecol 23: $287-297$

Lewis AR (1997a) Effects of experimental coral disturbance on the structure of fish communities on large patch reefs. Mar Ecol Prog Ser 161:37-50

Lewis AR (1997b) Recruitment and post-recruit immigration affect the local population size of coral reef fishes. Coral Reefs 16:139-149

Linton LR, Davies RW, Wrona FJ (1981) Resource utilization indices: an assessment. J Anim Ecol 50:283-292

Luckhurst BE, Luckhurst K (1978) Analysis of the influence of substrate variables on coral reef fish communities. Mar Biol 49:317-323

Mcllwain JL, Jones GP (1997) Prey selection by an obligate coral-feeding wrasse and its response to small-scale disturbance. Mar Ecol Prog Ser 155:189-198

Munday PL, Jones GP, Caley MJ (1997) Habitat specialisation and the distribution and abundance of coral-dwelling gobies. Mar Ecol Prog Ser 152:227-239

Pimm SL (1991) The balance of nature? Ecological issues in the conservation of species and communities. The University of Chicago Press, Chicago

Roberts CM, Ormond RFG (1987) Habitat complexity and coral reef fish diversity and abundance on Red Sea fringing reefs. Mar Ecol Prog Ser 41:1-8

Sale PF (1996) Structure and dynamics of reef fish communities: a biogeographical comparison. In: Cody ML, Smallwood JA (eds) Long-term studies of vertebrate communities. Academic Press, San Diego, p 73-97

Sale PF, Dybdahl R (1978) Determinants of community structure for coral reef fishes in isolated coral heads at lagoonal and reef slope sites. Oecologia 34:57-74

Sale PF, Guy JA, Steel WJ (1994) Ecological structure of assemblages of coral reef fishes on isolated patch reefs. Oecologia 98:83-99

Sano $M$ (1989) Feeding habits of Japanese butterflyfishes (Chaetodontidae). Environ Biol Fishes 25:195-203

Sano M, Shimizu M, Nose Y (1984a) Changes in structure of coral reef fish communities by destruction of hermatypic corals: observational and experimental views. Pac Sci 38: $51-79$ 
Sano M, Shimizu M, Nose Y (1984b) Food habits of teleostean reef fishes in Okinawa Island, southern Japan. Univ Mus Univ Tokyo Bull 25:1-128

Sano M, Shimizu M, Nose Y (1987) Long-term effects of destruction of hermatypic corals by Acanthaster planci infestation on reef fish communities at Iriomote Island, Japan. Mar Ecol Prog Ser 37:191-199

Smith CL (1973) Small rotenone stations: a tool for studying coral reef fish communities. Am Mus Novit 2512:1-21

Editorial responsibility: Charles Birkeland (Contributing Editor), Mangilao, Guam
Sorokin YI (1993) Coral reef ecology. Springer-Verlag, Berlin

Wiens JA, Parker KR (1995) Analyzing the effects of accidental environmental impacts: approaches and assumptions. Ecol Appl 5:1069-1083

Williams DMcB (1986) Temporal variation in the structure of reef slope fish communities (central Great Barrier Reef): short-term effects of Acanthaster planci infestation. Mar Ecol Prog Ser 28:157-164

Submitted: July 4, 1999; Accepted: November 24, 1999 Proofs received from author(s): April 19, 2000 